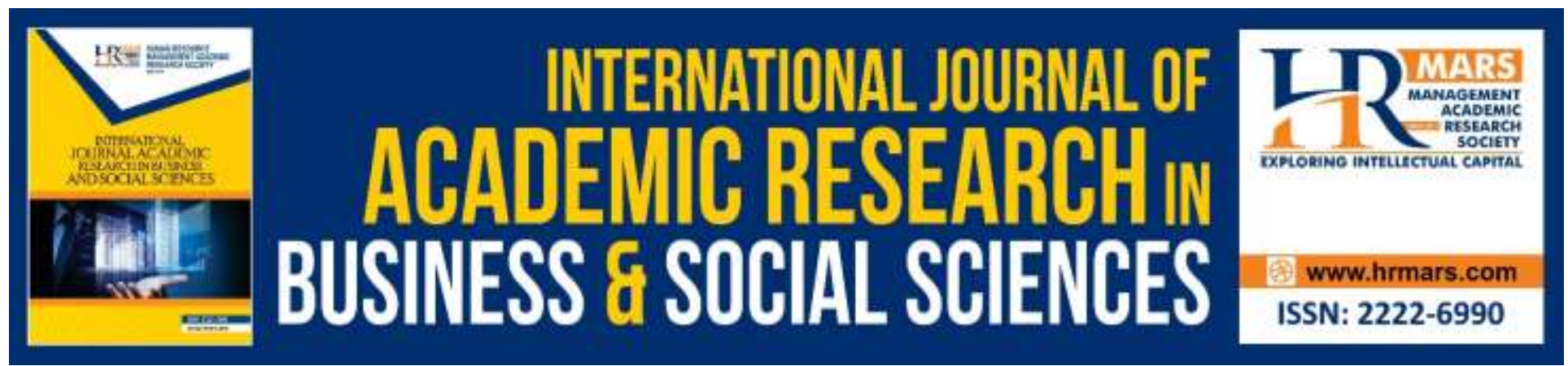

\title{
Client's Satisfaction in Face-To-Face Counselling and Cyber Counseling Approaches: A Comparison
}

Zaida Nor Zainudin, Yusni Mohamadd Yusop

To Link this Article: http://dx.doi.org/10.6007/IJARBSS/v8-i3/3992
DOI:10.6007/IJARBSS/v8-i3/3992

Received: 20 Feb 2018, Revised: 02 Mar 2018, Accepted: 15 Mar 2018

Published Online: 16 Mar 2018

In-Text Citation: (Zainudin \& Yusop, 2018)

To Cite this Article: Zainudin, Z. N., \& Yusop, Y. M. (2018). Client's Satisfaction in Face-To-Face Counselling and Cyber Counseling Approaches: A Comparison. International Journal of Academic Research in Business and Social Sciences, 8(3), 702-710.

Copyright: (C) 2018 The Author(s)

Published by Human Resource Management Academic Research Society (www.hrmars.com) This article is published under the Creative Commons Attribution (CC BY 4.0) license. Anyone may reproduce, distribute, translate and create derivative works of this article (for both commercial and non-commercial purposes), subject to full attribution to the original publication and authors. The full terms of this license may be seen at: http://creativecommons.org/licences/by/4.0/legalcode

Vol. 8, No. 3, March 2018, Pg. 702 - 710

Full Terms \& Conditions of access and use can be found at http://hrmars.com/index.php/pages/detail/publication-ethics 


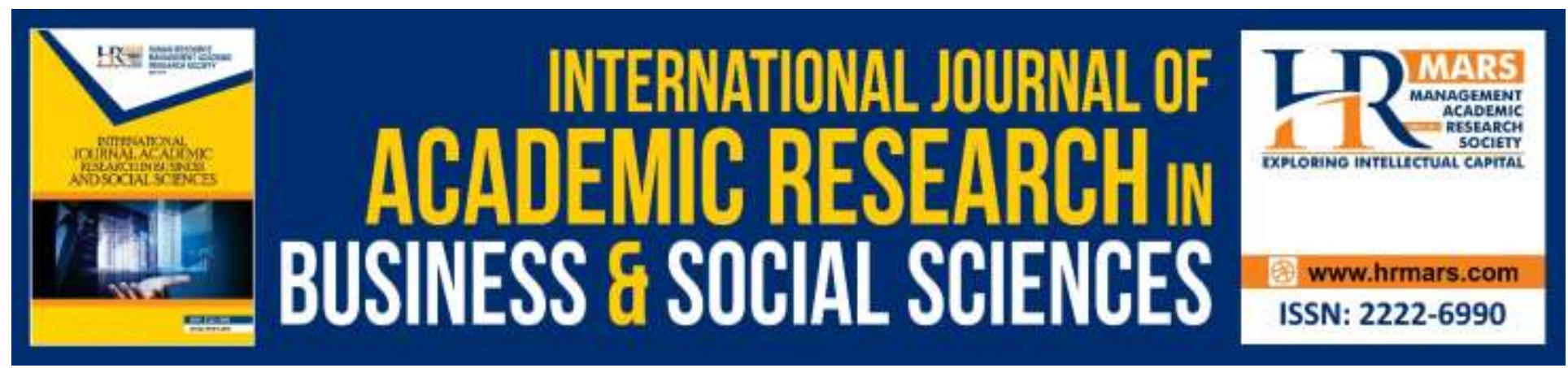

\title{
Client's Satisfaction in Face-To-Face Counselling and Cyber Counseling Approaches: A Comparison
}

\author{
Zaida Nor Zainudin, PhD, Yusni Mohamadd Yusop, PhD \\ Faulty of Educational Studies. University Putra of Malaysia. Malaysia
}

\begin{abstract}
This research is an attempt to explore the effectiveness of Cybercounseling services. In this research, the success of the Cybercounseling service is measured in terms of the capability of this method to provide client satisfaction (Client Satisfaction). This quasi-experimental study uses Non-equivalent Control Group Pretest/Postest Design. Quantitative data obtained using the Client's Satisfaction Inventory Short-Form (CSI-SF) questionnaire. A total of 60 research subjects were involved and conducted in two study groups, control group using Face-to-Counseling approach and experimental group using Cybercounseling approach. The findings show that Client Satisfaction in Cybercounseling approach is higher than Client Satisfaction in Face-to-face Counseling approach.
\end{abstract}

Keywords: Cybercounseling, Face-To-Face Counseling, Client's Satisfaction, Online Counselling.

\section{Background}

Counseling is a process to provide assistance based on psychological principles by professional counselors. This helpful relationship is to help clients move towards for a better change in their life. (Sharf, 2000). In this 22nd century, on the advanced of technology, changes in counseling services is no exception. In the cyberspace world, there is a new services offered in counselling services. Counseling services can now be carried out without having to meet face-toface. The role of the counselor has changed due to the influence of this sophisticated communication and intimate setting can be created virtually (Amla et al, 2014; Skinner \& Latchford, 2006; Oravec, 2000).

The cyberspace creates an infrastructure to build relationships, so the counseling practitioners has taken the initiative to maximize their services. An alternative service helps through this virtual interaction is created and practised. This virtual counselling service is known as cybercounseling. This service is also known as web-counseling, cyber-counseling, cyber-therapy and e-therapy (Manhal-Baugus, 2001).

This cybercounseling service has risen rapidly as many qualified counselors began offering cybercounseling services (Amla et al, 2014; Bengtsson et al, 2015). International Society for Mental Health Online (ISMHO) counted 5000 websites offered cybercounseling services. (Dawn, 
2004). Some other studies also show a drastic improvement in cybercounseling services (Griffith, 2005). This increase is expected because counselors no longer place modernity as an obstacle but instead see the Internet as a potential and convenience (Dawn, 2004; Lunt, 2004).

The practises of the Cybercounseling services and the recognition of Cybercounseling services is uncertain in its effectiveness. High curiosity among counseling practitioners led them to conduct a survey to measure the effectiveness of this service compared to conventional methods of Faceto-Counseling (Bengtsson et al, 2015). Many studies show the effectiveness of cybercounseling services as opposed to Face-to-Counseling in various aspects. There are comparative studies in counselor-client relationships (Cook \& Doyle, 2002; Yager, 2000), counseling session impact studies (Reynolds, Stiles and Grohol, 2006), bulimia problem programs (Robinson \& Serfaty, 2001 ), client satisfaction (Chester \& Glass, 2006; Leibert, Archer, Munson and York, 2006), and grief (Barak \& Bloch, 2006). Studies have also shown the effectiveness of service on adolescents (Barak \& Dolev-Cohen, 2006; King et al., 2006; Lekic, 2006; Skinner \& Latchford, 2006). The findings also show that Cybercounseling can reduce stress levels (Menon \& Rubin, 2011).), and provide emotional relief (Barak \& Dolev-Cohen, 2006; Lekic, 2006; King et al, 2006). All studies have shown positive results on the effectiveness of Cybercounseling services to adolescents associated with anonymous elements (Lekic, 2006), time flexibility (King et al., 2006; Skinner \& Latchford, 2006), anonymity (Lekic, 2006), simple access (Skinner \& Latchford, 2006) and client engagement (Barak \& Dolev-Cohen, 2006).

\section{Problem Statement}

The e-counseling and the recognition of e-counseling services to the e-counseling service is uncertain to ensure its effectiveness. High curiosity among counseling practitioners led them to conduct a survey to measure the effectiveness of this service compared to conventional methods of face-to-face counseling (Barnett, 2005). Many articles display the results of the study that have been conducted to see the effectiveness of cybercounseling services versus face-toface counseling. The comparison is done using a variety of research instruments to measure the results of different studies. Research findings show cybercounseling is better than face-to-face counseling (Barak \& Bloch, 2006; Cook \& Doyle, 2002; Reynolds, Stiles and Grohol, 2006 and Yager, 2000). There are also research findings that show face-to-face counseling and cyber counseling have the same effectiveness (Barak \& Dolev-Cohen, 2006; Chester \& Glass, 2006; Leibert, Archer, Munson and York, 2006; Mallen, Day \& Green , 2003; Robinson \& Serfaty, 2001). So there is a need to see the empirical data to prove these findings, as well as to enrich the pool of data on cybercounselling services. The findings also can be an empirical data of comparison on how cybercounseling is perceived and accepted in Malaysia.

\section{Methodology}

A quantitative study was carried out on 60 respondents in two study groups; the group in face-to-face approach and the Cybercounseling approach. Respondents are students of a school in Putrajaya, Malaysia. The research method is Quasi-Experimental Non-equivalent Control Group Pretest/Postest Design.

The dependent variable in this study is Client Satisfaction. To measure Client Satisfaction, the Client Satisfaction Instrument (CSI-SF) is used to measure client's satisfaction after obtaining 
counseling services. Data is then analyzed using Independent T-test to see the difference in client satisfaction that exists in both counseling methods.

A counseling session conducted through a complete counseling process and adheres to all the ethics of counseling. For a face-to-face counseling approach, the session is held at the School's Counseling Room, while Cybercounseling approach is carried out using 'Instant Messenger' modality. All respondents had a complete counseling session between 4 to 8 sessions. After the respondent completed the counseling process, they were given the CSI-SF instrument.

\section{Findings}

For control groups using face-to-face counseling approach, there were four male respondents (13.3\%) and 26 females (86.7\%). For the experimental group using the cybercounseling approach, three respondents were male (10\%) and 27 respondents were female (90\%). The total number of respondents was seven males and 53 females. Gender balance can not be controlled to adhere to the counseling ethics as well as the walk-in principle in the study procedure.

Respondents are in the age group of 13-18 years old which is the age range of students in high school in Malaysia. Respondents according to age in the control group were 22 respondents (73.3\%) ranging from 13 to 15 years old, and 8 respondents $(26.7 \%)$ in the range of 16 to 18 years. Experimental groups showed that 21 respondents (70\%) were aged between 13 and 15 years and 9 respondents (30\%) were in the range of 16 to 18 years.

Table 1: Respondents' profile

\begin{tabular}{|c|c|c|}
\hline \multirow[t]{2}{*}{ DEMOGRAPHY } & \multicolumn{2}{|l|}{ GROUP } \\
\hline & $\begin{array}{c}\text { CONTROL } \\
\text { (Face-to-face) } \\
n=30\end{array}$ & $\begin{array}{l}\text { EXPERIMENT } \\
\text { (Cybercounseling) } \\
n=30\end{array}$ \\
\hline \multicolumn{3}{|l|}{ GENDER } \\
\hline Male & $4(13.3 \%)$ & $3(10.0 \%)$ \\
\hline Female & $26(86.7 \%)$ & 27 (90.0\%) \\
\hline \multicolumn{3}{|l|}{ AGE } \\
\hline 13 to 15 years & $22(73.3 \%)$ & $21(70.0 \%)$ \\
\hline 16 to 18 years & $8(26.7 \%)$ & 9 (30.0\%) \\
\hline
\end{tabular}

Client Satisfaction Stage is measured using the Client Satisfaction Instrument-Short Form by Mc Murtry \& Hudson, 2004. It has four levels; Very High (Score 80-100), High (score 60-79), Moderate (score 40-59) and Low I (score 1-39).

The analysis was conducted on both groups of studies. The research findings show that in the face-to-face counseling approach, $14(47 \%)$ of the respondents showed very high satisfaction level, 11 (37\%) were in the high level, four (13\%) were moderate and one (3\%) was at low satisfaction level. However, the findings of the Cybercounseling approach, 27 respondents (90\%) were in Very High satisfaction level, and three (10\%) were in High level. Analysis is described in Table 2 for both groups. 
Table 2: Client's satisfaction between groups

\begin{tabular}{lccc}
\hline SATISFACTION LEVEL & $\begin{array}{c}\text { CONTROL } \\
\text { (face-to-face) } \\
n=30\end{array}$ & $\begin{array}{c}\text { EXPERIMENT } \\
\text { (cybercounseling) } \\
n=30\end{array}$ & \\
\hline Low & $1(3 \%)$ & 0 & \\
Moderate & $4(13 \%)$ & 0 & \\
High & $11(37 \%)$ & $3(10 \%)$ & $27(90 \%)$ \\
Very high & $14(47 \%)$ & &
\end{tabular}

Next, means for each items in Client Satisfaction Instrument is compared between these two groups. From Table 3, the means show that Cybercounseling clients are higher on their satisfaction in all items compared to Face-to-Face Counseling clients. The items that showed the highest mean difference between the two groups were item 3 with mean difference of 1.1666 and item 8 with mean difference 1.0667. This means that clients of the Cybercounseling group feel they will recommend this service to their friends. Item 8 also means that clients of the group of Cybercounseling approach has more comfortble in communicating and expressing their problems to counselor.

Table 3: Mean Difference of client's satisfaction

\begin{tabular}{|c|c|c|c|}
\hline Item & Approach & Mean & Mean difference \\
\hline \multirow{3}{*}{$\begin{array}{l}\text { 1. People here really seem to care } \\
\text { about me. }\end{array}$} & Cybercounselin & 6.7000 & .4667 \\
\hline & g & & \\
\hline & Face-to-face & 6.2333 & \\
\hline \multirow{4}{*}{$\begin{array}{l}\text { 2. I would come back here if I need } \\
\text { help again }\end{array}$} & Cybercounselin & 6.6000 & .3333 \\
\hline & g & & \\
\hline & & 6.2667 & \\
\hline & Face-to-face & & \\
\hline \multirow{3}{*}{$\begin{array}{l}\text { 3. I would recommend this place } \\
\text { to people I care about. }\end{array}$} & Cybercounselin & 6.3333 & 1.1666 \\
\hline & g & & \\
\hline & Face-to-face & 5.1667 & \\
\hline \multirow{4}{*}{$\begin{array}{l}\text { 4. People here really know what } \\
\text { they are doing. }\end{array}$} & Cybercounselin & 6.6333 & .7000 \\
\hline & g & & \\
\hline & & 5.9333 & \\
\hline & Face-to-face & & \\
\hline \multirow{3}{*}{$\begin{array}{l}5 . \text { I get the kind of help here that I } \\
\text { really need. }\end{array}$} & Cybercounselin & 6.5333 & .7666 \\
\hline & g & & \\
\hline & Face-to-face & 5.7667 & \\
\hline \multirow{4}{*}{$\begin{array}{l}\text { 6. People here accept me for who I } \\
\text { am }\end{array}$} & Cybercounselin & 6.7333 & .5000 \\
\hline & g & & \\
\hline & & 6.2333 & \\
\hline & Face-to-face & & \\
\hline \multirow{2}{*}{$\begin{array}{l}\text { 7. People here seem to } \\
\text { understand how I feel. }\end{array}$} & Cybercounselin & 6.3667 & .7000 \\
\hline & $\mathrm{g}$ & & \\
\hline
\end{tabular}


INTERNATIONAL JOURNAL OF ACADEMIC RESEARCH IN BUSINESS AND SOCIAL SCIENCES

Vol. 8, No.3, March 2018, E-ISSN: 2222-6990 @ 2018 HRMARS

\begin{tabular}{llll} 
& Face-to-face & 5.6667 & \\
\hline $\begin{array}{l}\text { 8. I feel I can really talk to people } \\
\text { here. }\end{array}$ & $\begin{array}{l}\text { Cybercounselin } \\
\mathrm{g}\end{array}$ & 6.6000 & 1.0666 \\
& Face-to-face & 5.5333 & \\
\hline $\begin{array}{l}\text { 9. The help I get here is better } \\
\text { than I expected. }\end{array}$ & Cybercounselin & 6.5667 & .8666 \\
& $\mathrm{~g}$ & 5.7000 & \\
& Face-to-face & & \\
\hline
\end{tabular}

To measure the difference of Client Satisfaction in these two counseling approaches, independent t-test was run to test. The t-test analysis showed that there was a significant difference between the Face-to-Counseling and Cybercounseling approaches with $\mathrm{t}$-value = $4.009, p<.05$. Client satisfaction in the Cybercounseling approach (mean $=1.9000$ ) was higher than the face-to-face approach (mean $=1.4667$ ) with mean difference of .4333 . This finding clarifies that clients in the Cybercounseling approach show higher satisfaction compared to faceto-face approach.

Table 4: Mean difference of client's satisfaction

\begin{tabular}{llllllll}
\hline Approach & $\mathrm{n}$ & mean & mean diff. & $\mathrm{sd}$ & $\mathrm{df}$ & $\mathrm{t}$ & sig. $\mathrm{p}$ \\
\hline Face-to-face & 30 & 1.4667 & & .5074 & & & \\
& & & .4333 & & 58 & 4.009 & $.000^{*}$ \\
Cybercounseling & 30 & 1.9000 & & .3051 & & & \\
\hline
\end{tabular}

- $\mathrm{p}<.05$

\section{Discussions}

The study looked at the comparison of client satisfaction in both counseling methods and the findings showed significant differences in client satisfaction in face-to-face counseling and cybercounseling. Through advanced analysis, client satisfaction in cybercounseling was higher than the face-to-face Counseling method. This finding is consistent with Cook \& Doyle findings (2002) which shows that E-Counseling services receive higher satisfaction scores when compared to face-to-face counseling. It is parallel with the findings of Barak \& Bloch, 2006; Reynolds, Stiles and Grohol, 2006and also and Yager, 2000.

Among the other factors stated to contribute to client satisfaction is the client's willingness to share the grief as stated by Reynolds et al. (2006), positive attitude of clients (Robinson \& Serfaty, 2001) and the therapeutic environment created by cybercounselor (King et al., 2006). Skinner \& Latchford (2006) proved that cybercounseling services are as effective as face-to-face Counseling for the easy access factors that enable them to get immediate answers and insights compared to scheduled Face-to-face Counseling.

Another factor is the internet as a medium. King at al (2006) and Lekic (2006) mentioned that the Internet is the most strategic medium to help teens because they are not worried about the counselor's reaction when discussing an issue, and also they can get online help 
instantaneously. This situation is very different from the face-to-face counseling sessions that require them to meet on a scheduled basis and sometimes the help is needed beyond the scheduled counseling sessions.

\section{Conclusions}

The findings of the present study enhance current knowledge in cybercounseling effectiveness with more understanding of the client's satisfactions. While new understanding of cyber counseling relationship is highlighted, these studies also support evidences, indicating the level of clients satisfactions in both approaches. However, due to small sample size, it limits the generalizability of our findings. It is especially important to replicate this study with a larger sample and more diverse groups to be able to attain more evidence of the effectiveness of cybercounselling services.

The mean differences compared in each items also showed significant differences in cybercounselling compared to face-to-face counseling. The cybercounseling clients post their satisfactions in the term of services, theraputic environment as well as the counselor. The mean differences as a whole client's satisfacition also significant as the cybercounseling approach score higher compared to face-to-face counseling.

\section{Corresponding Author}

Dr Zaida Nor Zainudin

Department of Counsellor Education \& Counselling Psychology, Faculty of Educational Studies, 43400 UPM Serdang, Selangor, MALAYSIA

Email: zaidanor@upm.edu.my

\section{References}

Barak, A., \& Bloch, N. (2006). Factors Related to Perceived Helpfulness in Supporting Highly Distressed Individuals through an Online Support Chat. CyberPsychology \& Behavior. 9(1), 60-68.

Barak, A., \& Dolev-Cohen, M. (2006). Does activity level in online support groups for distressed adolescent determine emotional relief. Counselling \& Psychotherapy Research, 6(3), 120124.

Barnett, R. (2005). Uncovering Sex and Gender Differences in Use Patterns of Self-help and Support Group: Annotated Bibliography and Research Agenda. Prairie Women's Health Centre of Excellence, Winnipeg MB

Bengtsson, J., Nordin, S., \& Carlbring, P. (2015). Therapists' Experiences of Conducting Cognitive Behavioural Therapy Online vis-à-vis Face-to-Face. Journal Cognitive Behaviour Therapy, 44(6).

Cook, J. E., \& Doyle, C. (2002). Working alliance in online therapy as compared to face-to-face therapy: Premilinary results. CyberPsychology \& Behavior, 5(2): 95-105.

Chester, A., \& Glass, C. (2006). Online Counselling: A descriptive analysis of therapy services on the Internet. British Journal of Guidance \& Counselling, 34 (2), 145-160. 
Dawn, D. (2004). Clinical and demographic features of the online counselling client population. Counselling \& Psychoterapy Research Journal, 4(1), 18-22.

Dowling, M., \& Rickwood, D. (2013). Online Counseling and Therapy for Mental Health Problems: A Systematic Review of Individual Synchronous Interventions Using Chat. Journal of Technology in Human Services, 31(1)

Finn, J., \& Barak, A. (2010). A descriptive study of e-counsellor attitudes, ethics, and practice. Counselling and Psychotherapy Research, 10(4), 268-277

Griffith, M. D. (2005). Online Therapy for Addictive Behaviors. Cyberpsychology \& Behavior. 8(6), 555-561.

King, R., Bambling, M., Reid, W., \& Thomas, I. (2006). Telephone and online counseling for youth people: A naturalistic comparison of session outcome, session impact and therapeutic alliance. Counselling \& Psychotherapy Research, 6(3), 109-115.

King, R., Bambling, M., Reid, W., Lloyd, C., Gomurrra, R., Smith, S., \& Wegner, K. (2006). Online counseling: The motives and experiences of young people who choose the internet instead of face to face or telephone counseling. Counselling \& Psychotherapy Research, 6(3), 103-108.

Leibert, T., Archer, J. J., Munson, J., \& York, G. (2006). An exploratory study of client perceptions of internet counseling and the therapeutic alliance. Journal of Mental Health Counseling, 28(1): 69-83.

Lekic, K. (2006). Growing up with counseling online. Psychiatria Danubina, 18(1).

Lunt, P. T. (2004). Adolescents' Willingness to Utilize Online Counseling. Doctoral Deseration, Virginia Polytechnic Institute and State University, USA.

McMurtry, S. L., \& Hudson, W. W. (2000). The client satisfaction inventory: Results of an initial validation study. Research on Social Work Practice, 10, 644-663.

Mallen, M. J., Vogel, D. L., \& Rochlen, A. B. (2005). The Practical Aspects of Online Counselling: Ethics, Training, Technology, and Competency. The Counseling Psychologist, 33(6), 776818.

Manhal-Baugus, M. (2001). E-Therapy: Practical, Ethical and Legal Issues. Cyberpsychology \& Behavior, 4(5), 551-563.

Menon, G. M., \& Rubin, M. (2011). A Survey of Online Practitioners: Implications for Education and Practice. Journal of Technology in Human Services, 29(2).

Oravec, J. A. (2000). Online counselling and the Internet: Perspectives for Mental Health Care Supervision and Education. Journal of Mental Health, 9(2): 121-136.

Oravec, J. A. (2000). Internet and computer technology hazards: perspective for family counseling. British Journal of Guidance \& Counselling, 28(3), 309-324.

Reynolds Jr., D.J., Stiles, W. B., \& Grohol, J. B. (2006). An investigation of session impact and alliance in internet based psychotherapy: Preliminary results. Counselling \& Psychotherapy Research, Sept 2006, 6(3), 98-102.

Robinson, P. H., \& Serfaty, M. A. (2001). The use of e-mail in the identification bulimia nervosa and its treatment. European Eating Disorders Review, 9, 182-193.

Robson, D., \& Robson, M. (2000). Ethical issues in internet counseling. Counselling Psychology Quarterly, 13(3), 249-257.

Sharf, R. S. (2000). Theories of psychotherapy \& counseling: Concepts and cases. USA: Brooks/Cole. 
INTERNATIONAL JOURNAL OF ACADEMIC RESEARCH IN BUSINESS AND SOCIAL SCIENCES

Vol. 8, No.3, March 2018, E-ISSN: 2222-6990 @ 2018 HRMARS

Skinner, A., \& Latchford, G. (2006). Attitudes to counseling vie the internet: A comparison between in-person counseling clients and internet support group users. Counselling \& Psychotherapy Research, 6(3), 158-163.

Yager, J. (2000). E-mail as therapeutic adjunct in the outpatient treatment of anorexia nervosa: Illustrative case material and discussion of the issues. International Journal of Eating Disorder, 29, 125-138. 